Research Paper

\title{
Production of humic substances through coal-solubilizing bacteria
}

\author{
Nelson Valero ${ }^{1,2}$, Liliana Gómez ${ }^{1}$, Manuel Pantoja ${ }^{1}$, Ramiro Ramírez ${ }^{3}$ \\ ${ }^{1}$ Laboratory of Environmental and Agricultural Microbiology, Universidad Popular del Cesar, \\ Campus Sabanas, Valledupar, Colombia. \\ ${ }^{2}$ Faculty of Basic Science, Universidad de La Guajira, Riohacha, Colombia. \\ ${ }^{3}$ Soil Physics Laboratory, Universidad Nacional de Colombia, Medellín, Colombia.
}

Submitted: June 16, 2013; Approved: March 14, 2014.

\begin{abstract}
In this paper, the production of humic substances (HS) through the bacterial solubilization of low rank coal (LRC) was evaluated. The evaluation was carried out by 19 bacterial strains isolated in microenvironments with high contents of coal wastes. The biotransformed LRC and the HS produced were quantified in vitro in a liquid growth medium. The humic acids (HA) obtained from the most active bacterial strain were characterized via elemental composition $(\mathrm{C}, \mathrm{H}, \mathrm{N}, \mathrm{O})$, IR analyses, and the $\mathrm{E}_{4} / \mathrm{E}_{6}$ ratio; they were then compared with the $\mathrm{HA}$ extracted chemically using $\mathrm{NaOH}$. There was LRC biotransformation ranged from 25 to $37 \%$, and HS production ranged from 127 to $3100 \mathrm{mg} . \mathrm{L}^{-1}$. More activity was detected in the isolated strains of Bacillus mycoides, Microbacterium sp, Acinetobacter $s p$, and Enterobacter aerogenes. The HA produced by B. mycoides had an IR spectrum and an $\mathrm{E}_{4} / \mathrm{E}_{6}$ ratio similar to those of the $\mathrm{HA}$ extracted with $\mathrm{NAOH}$, but their elemental composition and their degree of aromatic condensation was different Results suggest that these bacteria can be used to exploit the LRC resulting from coal mining activities and thus produce HS in order to improve the content of humified organic matter in soils.
\end{abstract}

Key words: low rank coal, Microbacterium sp, Bacillus mycoides, Acinetobacter baumannii, Enterobacter aerogenes.

\section{Introduction}

Humic substances (HS) are considered large supramolecular arrays resulting from the self-assembling of relatively small heterogeneous humic molecules derived from the degradation of biological materials. These supramolecular associations are stabilized by hydrogen bridges and weak hydrophobic bonds such as the Van der Waals forces, $\pi-\pi$, and $\mathrm{CH}-\pi$ (Piccolo 2002). The HS in the soil play an important role in physical and chemical quality, carbon capture and stabilization (Piccolo et al., 2004), and in the inactivation of pesticides, heavy metals, and other polluting agents (Bandeira et al., 2009). HS also stimulate plant physiology (Badis et al., 2009), induce root proliferation, and modify the architecture of the root system (Barros et al., 2010). As a result of this, HS stimulate plant growth and development (Trevisan et al., 2010).
Currently, HS are commonly used as organic amendments for agricultural soils. Low rank coals (LRC) such as peat, leonardite, and lignites are not exploited commercially due to their low energetic power. However, they are considered a HS-rich source. To obtain HS from this source, the classical method, i.e. extraction using alkaline solutions, is used (Senesi et al., 2007; Chassapis and Roulia, 2008). Nevertheless, there is increased interest in solubilizing coal through the ligninolytic microorganisms in the soil as an alternative procedure to obtain HS. The coal solubilization processes that have been studied in greater detail include the basidiomycetes fungi involved in wood rotting processes. These fungi are: Trametes versicolor (Ralph and Catchside, 1996), Nematoloma frowardii (Hofrichter and Fritsche, 1997), and Phanerochaete chrysosporium (Ralph and Catchside, 1997). Likewise, saprophytic soil fungi such as Trichoderma atroviridae (Holker and Hofer, 2002; Oboirien

Send correspondence to N. Valero. Laboratory of Environmental and Agricultural Microbiology, Universidad Popular del Cesar, Campus Universitario sede Sabanas, Avenida Fundación, Valledupar, Colombia. E-mail: nelsonvalero@unicesar.edu.co. 
et al., 2008) and Penicillium decumbens (Yin et al., 2009) have also been studied.

Despite the advances in the understanding of the microbial transformation of coal, it is still not possible to develop efficient and economically viable biotechnological processes to produce HS by solubilizing LRC with fungi. The main reason is the difficulty in handling coal in bioreactors and the loss of process stability due to a complex regulation of the solubilization mechanisms. Furthermore, the main mechanism for coal solubilization through fungi is the production of ligninolytic enzymes (Willman and Fakousa, 1997; Gockay et al., 2001); however, it is often observed that depolymerization of the released HS takes place after coal solubilization (Hofrichter and Fritsche, 1997). This phenomenon has been associated with the activity of the laccase (Fakousa and Hofrichter, 1999; Ralph and Catcheside, 1998; Zaavarzinda et al., 2004), lignin peroxidase (Ralph and Catcheside, 1998b), and manganeso peroxidase enzymes (Hofrichter 2002). This depolymerization of HS leads to loss of their supramolecular conformation and consequently reduces their effect on soil properties and their bioactivity on plants.

There is another procedure for solubilizing coal that does not rely on fungi: coal solubilization through bacteria. This process uses non-enzymatic mechanisms such as the production of surfactants, chelators, and alkaline substances (Hofrichter and Fakoussa, 2004). Therefore this may be an alternative to prevent the depolymerization of the HS produced. There are studies on bacterial solubilization of coal through Escherichia freundii, Pseudomonas rathonis, Pseudomonas fluorescens, Streptomyces setoni, (Laborta et al., 1997); Pseudomonas putida (Machnikouska et al., 2002), Rhodococcus spp (Fuchtenbusch and Steinbuchel, 1999), Bacillus, Rhodococcus, and Staphylococcus (Pokorny et al., 2005), as well as through the actinomycetes Streptomyces setonii (Willman and Fakoussa, 1997) and Streptomyces viridosporous (Strandberg and Lewis, 1987). Recent studies have described the role that the actinomycetes with ligninolytic activity play in the regulation of the polymerization of HS in the soil. (Badis et al., 2009).

This study aimed to evaluate the solubilization of LRC derived from hard coal mining activities in the "El Cerrejón" open cast mine (La Guajira, Colombia).The goal was to analyze the production of HS due to the activity of native bacteria isolated from microenvironments with high contents of coal waste. This study seeks to advance in the development of a strategy for use or final disposal of LRC directly on the soil by means of bioaugmentation with coal solubilizing bacteria to provide humified organic matter for use in land reclamation processes after mining activities, or for degraded soil due to organic matter loss.

\section{Materials and Methods}

Microorganisms: 19 bacteria strains were selected, which were isolated from soil mixed with coal residues, coal sediment resulting from coal washing, and the rhizosphere of Cenchrus ciliaris and Typha domingensis, two plants from the gramineae family which grow on soil and sediments with high amounts of coal particles in areas under the influence of the open pit coal extraction activities carried out in the "El Cerrejón" open cast mine (La Guajira - Colombia). These strains were selected because of their ability to grow in a (AMSC5) growth medium with powdered LRC at $5 \%$ as the only source of carbon. Its composition $(\mathrm{mg} / \mathrm{L})$ was: $\mathrm{NH}_{4} \mathrm{NO}_{3} 2.50, \mathrm{KH}_{2} \mathrm{PO}_{4} 1.75, \mathrm{MgSO}_{4}$ $0.75, \mathrm{~K}_{2} \mathrm{HPO}_{4} 0.75, \mathrm{NaCl} 0.25, \mathrm{ZnSO}_{4} 0.088, \mathrm{FeCl}_{3} 0.08$, $\mathrm{CuSO}_{4}$ 0.016, $\mathrm{MnCl}_{2}$ 0.014, $\mathrm{MoO}_{3}$ 0.007, $\mathrm{Co}\left(\mathrm{NO}_{3}\right)_{2}$ 0.005; noble agar 15 g.L $\mathrm{L}^{-1}$, powdered LRC 5\%(p/v) (Valero et al., 2011).

LRC Characterization and Extraction of HS Through the Classical Method: the LRC used in the study was extracted from mantle number 40 of the pit named "Tajo Patilla" of the "El Cerrejón" open cast mine (11 $05^{\circ} 45.54$ " $\mathrm{N}$ and $\left.72^{\circ} 40^{\prime} 66.55^{\prime \prime} \mathrm{W}\right)$. The LRC was sieved to obtain particles smaller than $300 \mu \mathrm{m}$. The content of heavy metals (As, $\mathrm{Co}, \mathrm{Pb}, \mathrm{V}, \mathrm{Cu}, \mathrm{Zn}, \mathrm{Ni}, \mathrm{Cr}, \mathrm{B}, \mathrm{Mo}$ and $\mathrm{Cd}$ ) was determined together with total humidity, ash content, calorific power, content of volatile substances, percentage of fixed carbon, sulfur, and minerals in the ashes $\left(\mathrm{Fe}_{2} \mathrm{O}_{3}, \mathrm{CaO}\right.$, $\mathrm{MnO}_{2}, \mathrm{MgO}, \mathrm{SrO}, \mathrm{K}_{2} \mathrm{O}, \mathrm{BaO}$ ). This was done in compliance with the AMTS (American Society for Testing and Materials) standards. Additionally, a Fisions Interscience EA 1108 analyzer was used to determine elemental composition $(\mathrm{C}, \mathrm{H}, \mathrm{O}, \mathrm{N})$.

The HS of the LRC were obtained through the classical extraction method using $0.5 \mathrm{M}$ of $\mathrm{NaOH}$. The fractions of humic acids (HA) and fulvic acids (FA) were separated in accordance with the protocol described by Sharif et al. (2002). The percentage of carbon in the total humic extract (THE) and in the fractions of HA and FA was determined by using the methodology described by the International Humic Substances Society (2007).

LRC Solubilization Test in a Solid Matrix: Each strain was massively cultivated on nutrient agar plates (Oxoid). Cultures were incubated for $48 \mathrm{~h}$ at $32{ }^{\circ} \mathrm{C}$. Afterwards, sterile LRC particles were placed on the culture's surface; their diameter ranged from 2.36 to $4.25 \mathrm{~mm}$, and they were incubated for 8 days at $30^{\circ} \mathrm{C}$. LRC solubilization was detected by the presence of a brown halo indicating HS diffusion around the particle (Steinbuchel 2001).

LRC Solubilization Test in a Submerged Growth Medium: the bacterial cultures in AMSC5 were used to prepare an inoculum with a concentration level of 0.5 in the McFarland scale. This preparation was inoculated into flasks containing $100 \mathrm{~mL}$ of nutrient broth supplemented with $0.001 \%$ of HS acting as an inducer of coal solubilizing activity (Yuan et al., 2006). The cultures were incubated at $37^{\circ} \mathrm{C}$ for $48 \mathrm{~h}$. Later on, $1 \mathrm{~g}$ of powdered LRC that had been previously sterilized by autoclave was added to each tube. The resulting cultures were then incubated at $30 \pm 2{ }^{\circ} \mathrm{C}$ in 
orbital shaking at $420 \mathrm{rpm}$. After 7 days, the $\mathrm{pH}$ was determined and each culture was centrifuged at $3200 \mathrm{rpm}$ for $15 \mathrm{~min}$. The brown supernatant was filtered on a Whatman paper whose pore diameter was $2.5 \mu \mathrm{m}$. Absorbance of the resulting filtrate was measured in a Genesis 20- 4001-4 spectrophotometer at $465 \mathrm{~nm}$ in order to estimate the amount of SH present in the medium (Yuan et al., 2006). The remaining LRC in each culture underwent three centrifugation (7000 rpm for $15 \mathrm{~min}$ ) and water washing cycles. It was then dried at $100^{\circ} \mathrm{C}$ until it reached constant weight. After this, the LRC was weighted to determine the percentage of LRC that had been transformed. The experiment was performed in triplicate. The growth medium with an addition of LRC and no inoculum was used as the control culture. The growth medium without LRC or inoculum was used as the target.

To determine the concentration of HS released from the LRC by bacterial activity into the growth medium, an absorbance curve was created using HS solutions with concentrations ranging from 0.1 and $1.6 \mathrm{mg} \cdot \mathrm{mL}^{-1}$. The equation of the curve made it possible to conduct a linear regression analysis using the absorbance values taken from the extracellular filtrates obtained. Results of percentages of CBR transformed, HS concentration in the medium and $\mathrm{pH}$ were subjected to a one-way analysis of variance, means of each variable were also compared trough Dunnet method with a significance level of $95 \%$, the ANOVA analysis and mean comparison tests were performed using SPSS software version 18.

Molecular Typing of Efficient Strains: the DNA of the bacteria strains with the best performance in terms of HS production was extracted. A $1465 \mathrm{pb}$ region of the $16 \mathrm{~s}$ ribosomal gene was amplified via PCR using primers $27 \mathrm{~F}$, $1492 \mathrm{R}, 518 \mathrm{~F}$, and $800 \mathrm{R}$. The products of the reaction were sequenced and assembled in a consensus sequence problem. This sequence was later compared with reference databases from the US National Center for Biotechnology Information (NCBI), thus generating the taxonomic classification by means of a phylogenetic tree of the group of 25 sequences that most closely resemble the consensus sequence.

Characterization of HA Through Elemental Analysis $(\mathrm{C}, \mathrm{H}, \mathrm{O}, \mathrm{N})$, Infrared Analysis (IR), and $\mathrm{E}_{4} / \mathrm{E}_{6}$ Ratio: the fraction of HA obtained from the LRC solubilization process using the bacterial strain with the best performance was compared with the fraction of $\mathrm{HA}$ obtained with $\mathrm{NaOH}$ $0.5 \mathrm{M}$. Elemental composition $(\mathrm{C}, \mathrm{H}, \mathrm{N}, \mathrm{O})$ was determined with a Fisions Interscience EA 1108 analyzer, and the result was corrected for the ash content in each sample, which was in turn determined through the combustion of $50 \mathrm{mg}$ of each sample at $650^{\circ} \mathrm{C}$ for $4 \mathrm{~h}$. To obtain the IR spectrum, diffuse reflectance was recorded with the subsequent Fourier transform (DRIFT) in a PE Spectrum One spectrometer equipped with an accessory for diffuse reflectance. During this process, up to 100 scans per sample were accumulated at a resolution of $4 \mathrm{~cm}^{-1}$. Before the DRIFT analysis, the dried samples were diluted by mixing them with $\mathrm{KBr}$ powder $(5 / 100 \mathrm{Wt} / \mathrm{Wt})$ in an agate mortar. To determine the $\mathrm{E}_{4} / \mathrm{E}_{6}$ ratio, $4 \mathrm{mg}$ of $\mathrm{HA}$ was dissolved in $10 \mathrm{~mL}$ of $\mathrm{NaHCO}_{3}$ $0.05 \mathrm{M}$, then $\mathrm{pH}$ was adjusted at 8.3 with $\mathrm{NaOH} 0.1 \mathrm{M}$, and finally, absorbance was measured at 465 and $665 \mathrm{~nm}$ in a GENESYS 10S UV-VIS spectrophotometer.

\section{Results}

LRC Characterization: the humidity of the LRC used in this study was $28.44 \%, 11.12 \%$ of the coal was ash, and $47.79 \%$ volatile substances. Similarly, the calorific power was $4781 \mathrm{Kcal}^{\mathrm{Kg}}{ }^{-1}, 41.09 \%$ of the coal had fixed carbon, and $0.13 \%$ of its composition was S. These results confirm that this is a lignite-type LRC given its humidity and high content of volatile materials and the fact that its calorific power is below $6390 \mathrm{kcal} / \mathrm{kg}^{-1}$. The elemental analysis showed that $46.04 \%$ of the LRC was C, $3.26 \% \mathrm{H}, 42.95 \%$ $\mathrm{O}$, and $1.38 \% \mathrm{~N}$. The minerals in the ash were $\mathrm{Fe}_{2} \mathrm{O}_{3} 4.24 \%$, $\mathrm{CaO} 69.3 \%, \mathrm{MnO}_{2}$ 0.14\%, $\mathrm{MgO} 9.37 \%$, $\mathrm{SrO} 0.89 \%, \mathrm{~K}_{2} \mathrm{O}$ $0.05 \%$, and $\mathrm{BaO} 0.08 \%$. The process for determining the presence of $\mathrm{As}, \mathrm{Co}, \mathrm{Pb}, \mathrm{V}, \mathrm{Cu}, \mathrm{Zn}, \mathrm{Ni}, \mathrm{Cr}, \mathrm{B}, \mathrm{Mo}$, and $\mathrm{Cd}$ yielded the following values respectively: $0.71,2.31,1.73$, $1.66,0.55,22.43,3.35,2.4,15.11,2.52$, and $0.08 \mathrm{ppm}$. The process for extracting HS from LRC using $\mathrm{NaOH} 0.5 \mathrm{M}$ reached a performance level of $44.68 \pm 7.27 \%$. The carbon content in the total humic extract (CTHE) was $32.91 \%$; the carbon in humic acids (CHA) was $24.31 \%$; and the carbon in fulvic acids (CFA) was $8.6 \%$.

LRC Solubilization in a Solid Matrix: four out of the 19 strains evaluated (CSB34, CSB10, CSB3, and CSB13), developed a brown halo around the LRC particle (Figure 1a). Their average diameters were $40,38,15$, and $12 \mathrm{~mm}$ respectively.

LRC Solubilization in a Submerged Growth Medium: all the bacterial cultures with LRC additions developed a brown color that is typically observed in HS (Yuan et al., 2006) (Figure 1b). Such color is associated with an increase in absorbance at $465 \mathrm{~nm}$. The concentration of HS reached values between 127 and $3100 \mathrm{mg} / \mathrm{L}$ (Figure 2a). The absorbance value observed at $465 \mathrm{~nm}$ in the control treatment indicates that spontaneous release of small amounts of HS from the LRC took place upon contact with the growth medium. The Dunnet comparison average analysis made it possible to group activities of the CSB into five groups (Figure 2a). There was a significant difference $(\alpha=0.05)$ between almost all the treatments and the control treatment. An exception to this was the isolated strains from group (a). Strains CSB3, CSB13, and CSB25, which make up group (d), were the most active, and their HS production ranged between 2000 and $3100 \mathrm{mg} / \mathrm{L}$. The values for LRC weight loss due to bacterial activity varied from 25 to $37 \%$ (Figure $2 b$ ). In addition, a weight loss rate of $6.7 \%$ was observed in the control treatment. 


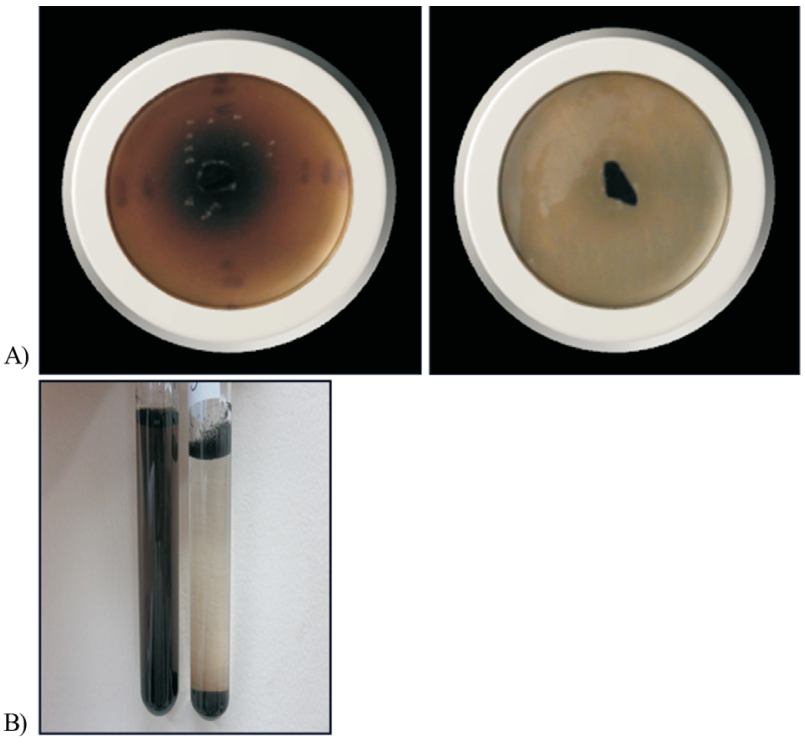

Figure 1 - LRC solubilization through bacteria: a) Expression of LRC solubilization through bacterial activity in a solid growth medium, activity of the CSB34 strain (left), Control (right). b) Evidence of solubilization shown by the production of brown soluble substances. Left: CSB25, Right: Control (growth medium + powdered LRC).
The addition of LRC raised the $\mathrm{pH}$ of the growth medium to a value close to 5 (Figure 3). Nevertheless, this change was reverted for all the bacteria cultures and the $\mathrm{pH}$ reached values ranging from 7.1 to 8.4. Likewise, a correspondence was observed between the strains with higher HS production (e.g. strains CSB3, CSB10, and CSB25) and higher $\mathrm{pH}$ values (8-8.5).

Molecular Typing: Table 1 shows the results of typing strains CSB 25, CSB3, CSB13, and CSB10, which showed the highest values regarding HS production in a liquid growth medium. The high rate of similarity between the identifiers of the gene bank and the analyzed sequences for the 4 strains studied indicates that these strains are likely to be Bacillus mycoides, Microbacterium sp, Acinetobacter $s p$. and Enterobacter aerogenes respectively. Of these genera, only the Bacillus genus has been reported due to its capacity to solubilize coal (Pokorny et al., 2005). The strains of the other three genera are new reports on coal solubilizing bacteria.

Characterization of the HA: the values of the $\mathrm{E}_{4} / \mathrm{E}_{6}$ ratio were 5.2 for the HA obtained through $B$ mycoides, and 4.8 for the HA obtained through the classical method.

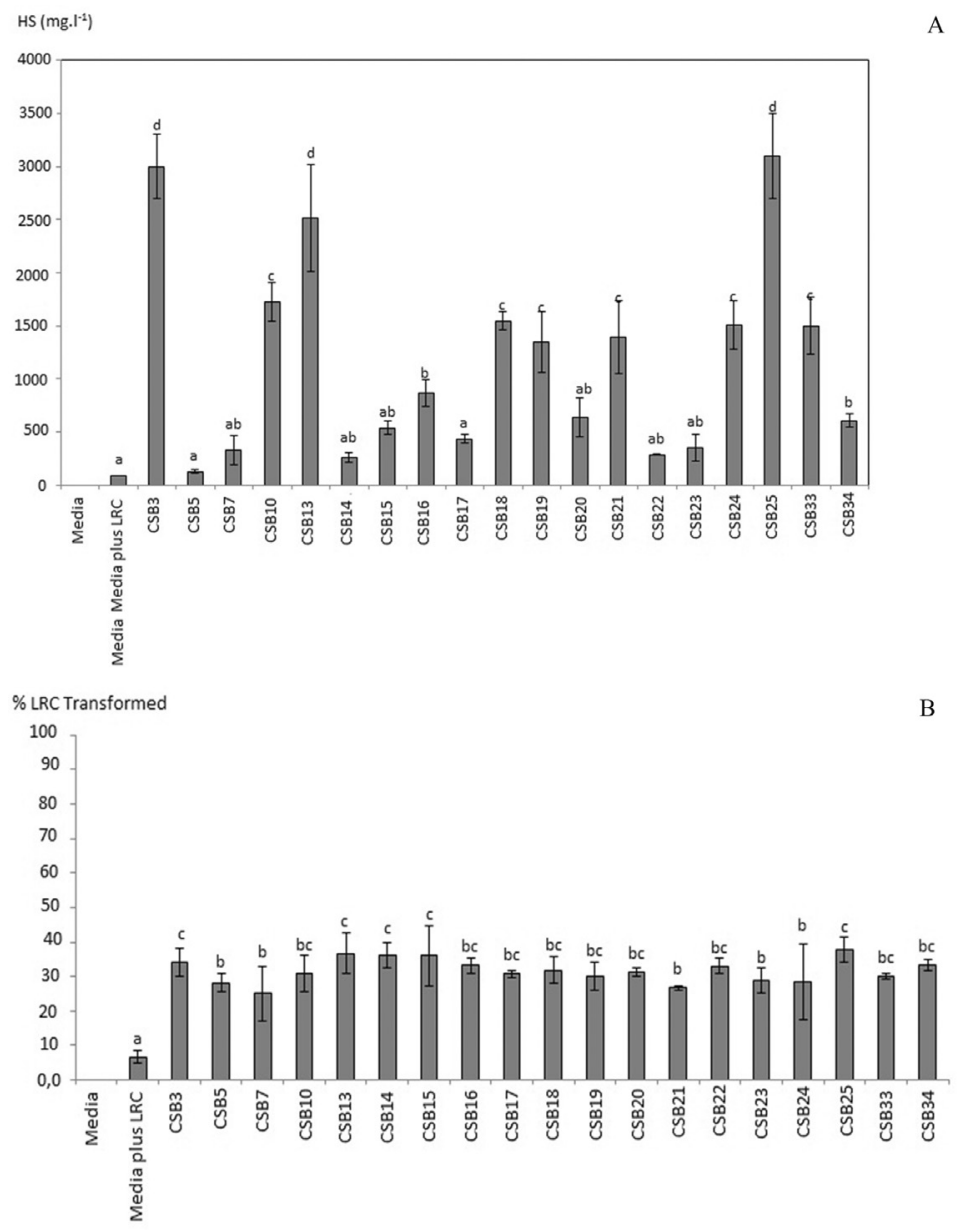

Figure 2 - LRC solubilization through bacterial activity in a submerged medium. a) HS production, b) percentage of transformed LRC. $\mathrm{n}=3$. Treatments with different letters show significant difference (Dunnet, $\alpha=0.05$ ) 


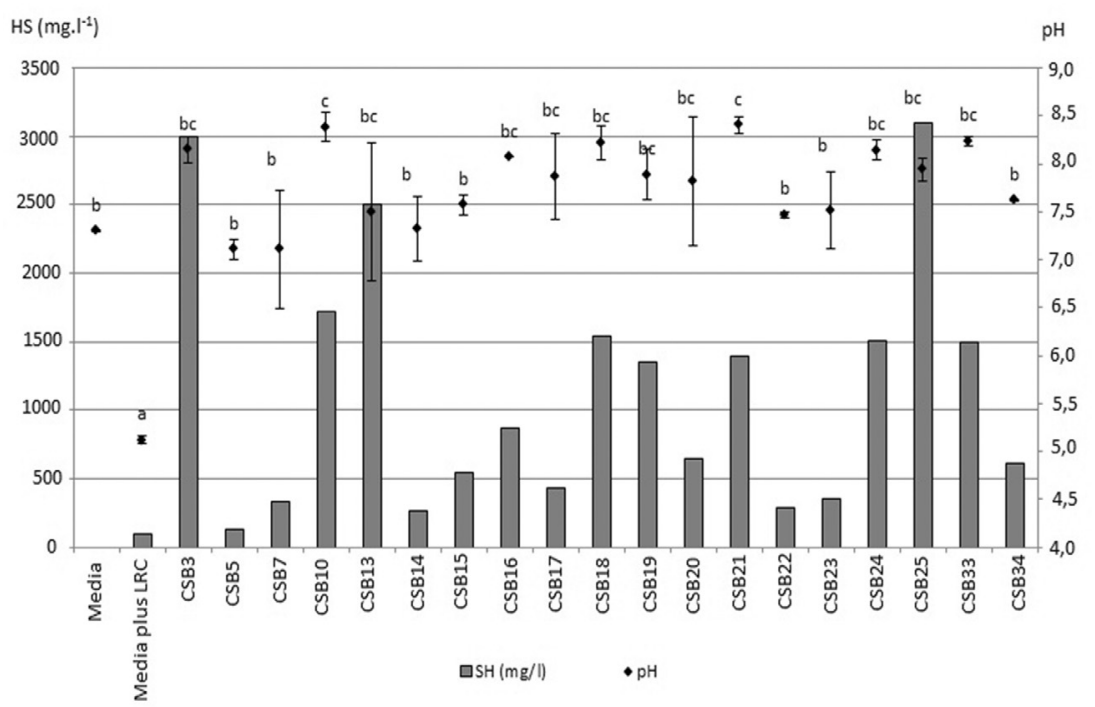

Figure 3 - Relationship of the final $\mathrm{pH}$ of the growth media to the HS production through $\mathrm{LRC} \mathrm{n}=3$. Treatments with different letters show significant difference (Dunnet, $\alpha=0.05$ ).

Table 1 - Molecular identification of four CSB with larger values of HS production.

\begin{tabular}{lcccc}
\hline Strain & Name & Identity $\%$ & Gene bank identifier (gi) & Acces number \\
\hline CSB25 & Bacillus mycoides str. BGSC1-DN3 & 98.95 & 288958 & AB368963.1 \\
CSB3 & Microbacterium sp. & 98.00 & 224555764 & FJ357539.1 \\
CSB13 & Acinetobacter sp. str. CCGE2017 & 99.40 & 569106 & EU867306.1 \\
CSB10 & Enterobacter aerogenes str. JCM1235 & 99.36 & 10039 & AB004750.1 \\
\hline
\end{tabular}

The IR spectra of the HA obtained through LRC solubilization with the CSB 25 strain (Bacillus mycoides) (Figure 4a) and those of the HA extracted with the classical method (Figure $4 \mathrm{~b}$ ) showed similar qualitative characteristics regarding the presence of organic functional groups.

There were vibrations due to the stretching of $\mathrm{O}-\mathrm{H}$ alcohols or phenols in polymeric association (3400$3200 \mathrm{~cm}^{-1}$ ). Likewise there were bending vibrations in the $\mathrm{O}-\mathrm{H}$ plane of alcohols and phenols around $1400 \mathrm{~cm}^{-1}$. Additionally, $\mathrm{C}=\mathrm{N}$ bond-stretching bands were observed between 2000 and $2600 \mathrm{~cm}^{-1}$ in secondary amides. Absorption bands were observed between 1500 and 1600 $\mathrm{cm}^{-1}$, which is associated with the $\mathrm{C}=\mathrm{C}$ vibrations typically observed in aromatic hydrocarbons and carboxylic groups. Around $1650 \mathrm{~cm}^{-1}$, a band was observed which corresponds to the vibration of the $\mathrm{C}=\mathrm{C}$ bonds conjugated with $\mathrm{C}=\mathrm{O}$ and
$\mathrm{COO}^{-}$; this band is related to the presence of unsaturated ketones, carboxyl groups or aryl esters as well as primary amides. Around $1100 \mathrm{~cm}^{-1}$ in the specter of the HA obtained through bacterial activity, a band was observed which is typically present in aromatic rings with para- and ortho-substitutions. Between 890 and $700 \mathrm{~cm}^{-1}$, bands were observed which are typically found when there is stretching in the $\mathrm{C}-\mathrm{O}-\mathrm{C}$ bonds of carbohydrates.

The elemental composition of the HA (See Table 2) showed a lower content of $\mathrm{N}, \mathrm{C}$, and $\mathrm{H}$, and a higher content of $\mathrm{O}$ in the $\mathrm{HA}$ obtained through classical methods.

\section{Discussion}

The percentage of extraction yield of HA through the classical method, CEHT, CAH, and CAF, indicates that the

Table 2 - Elemental composition of the HA obtained from LRC through alkaline extraction and through solubilization with B. mycoides.

\begin{tabular}{|c|c|c|c|c|c|c|c|c|c|c|}
\hline \multirow[t]{2}{*}{ HA } & \multirow[t]{2}{*}{$\mathrm{N} \%$} & \multirow[t]{2}{*}{ S D } & \multirow[t]{2}{*}{$\mathrm{C} \%$} & \multirow[t]{2}{*}{ S D } & \multirow[t]{2}{*}{$\mathrm{H} \%$} & \multirow[t]{2}{*}{ S D } & \multirow[t]{2}{*}{$\mathrm{O} \%$} & \multirow[t]{2}{*}{ S D } & \multicolumn{2}{|c|}{ Atomic ratio } \\
\hline & & & & & & & & & $\mathrm{O} / \mathrm{C}$ & $\mathrm{H} / \mathrm{C}$ \\
\hline Extracted with $\mathrm{NaOH}$ & 2.09 & 0.11 & 43.31 & 0.69 & 2.71 & 0.20 & 50.39 & 0.26 & 0.87 & 0.75 \\
\hline Obtained with $B$. mycoides & 5.64 & 0.08 & 51.49 & 0.19 & 3.83 & 0.02 & 36.19 & 1.24 & 0.53 & 0.89 \\
\hline
\end{tabular}

SD: standard deviation. 


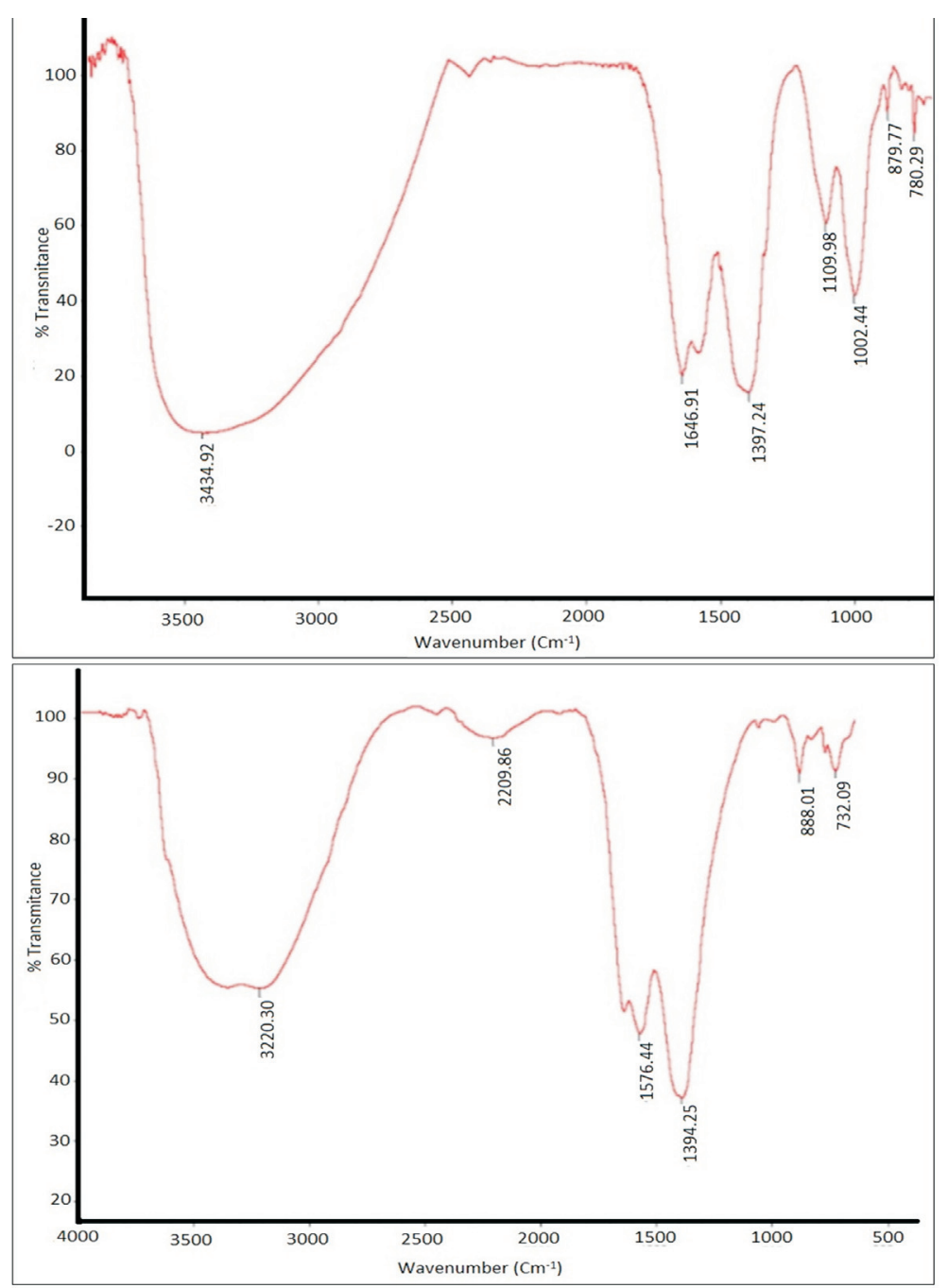

Figure 4 - IR spectra of a) HS obtained from LRC through the activity of Bacillus mycoides 240 (CSB25) and b) extracted from LRC using NaOH $0.5 \mathrm{M}$.

LRC used is a considerable source of HS; therefore it may be a substrate prone to the activity of coal solubilizing bacteria. The solubilization of LRC in a solid medium with the development of a brown halo has been previously observed for most LRC solubilizing fungi (Steinbuchel 2001) and for the Streptomyces setonii and Streptomyces viridosporous bacteria (Strandberg and Lewis, 1987).

The brown color, the increase in absorbance to $465 \mathrm{~nm}$ and the LRC weight loss in the control treatment provide evidence of the spontaneous solubilization of the LRC in the growth medium. The strains CSB3, CSB13, CSB10, and CSB25 which caused a greater production of HS also caused the greatest decline in LRC in the culture medium; although some strains that exhibit high values of transformed LRC produced low amounts of HS (CSB5, CSB7, CSB14,CSB15, CSB17, CSB20, CSB22 and CSB23). This result suggests that these strains have the ability to transform LRC but they also absorb the solubilized substances or transform them into other products other than HS; therefore, we can infer that all the strains un- der study exhibit a considerable ability to use and exploit LRC, but only some strains make it possible for HS to remain in the growth medium; these strains can be considered as the most efficient in terms of net production of HS.

The $\mathrm{pH}$ reached in the culture medium, despite the acidification effect from the LRC suggests that the CSB expressed the production of alkaline substances as one of the mechanisms to solubilize LRC; this phenomenon has been described in previous studies (Hofrichter et al., 1997; Yuan et al., 2006). The alkaline substances may be generated in the medium as a result of the transformation of nitrogen-rich compounds; for example, alkaline amines are produced as a result of the metabolism of peptones present in the nutrient broth (Hofrichter et al., 1997).

The values of the optical densities ratio $\left(\mathrm{E}_{4} / \mathrm{E}_{6}\right)$ for HA generally range between 3 and 8.5 (Stevenson 2004); the values ??found for the two types of HA in this study are considered to be similar and indicated an intermediate to high degree of humification; the result suggests that the supramolecular structure of the HA has a moderately high 
molecular weight, caused by molecules with a high aromatic condensation but with the presence of aliphatic chains, carboxylic groups, and an intermediate level of oxygen.

The IR analysis revealed no significant qualitative differences regarding the predominant organic groups in the macrostructure of the two HA types (Figure 3). However, the basic composition of the HA indicates that bacterial activity on the LRC generates $\mathrm{N}-, \mathrm{C}$-, and $\mathrm{H}$-enriched $\mathrm{HA}$, but with a lower oxygen content; this result evidences the activity of bacteria on the oxygen functional groups, which are the most reactive groups within the HS. This fact is possibly a direct consequence of the microbial metabolism that causes structural changes to the HA. The O/C atomic ratio is considered an indicator of carbohydrates and carboxylic groups, as well as the degree of humification (Canellas and Rocha, 2004); the decrease in this ratio suggests an increase in the HA aromatic condensation produced by B. mycoides, associated with the reduction of carbohydrates and carboxylic groups possibly used by bacteria. The value of the $\mathrm{H} / \mathrm{C}$ ratio also shows the level of maturity in the HS, because it indirectly reflects the existence of more condensed aromatic structures or substitutions in cyclic structures (Lu et al., 2000). The result evidences that the HA obtained through $B$. mycoides have a higher aromatic condensation and a lower content of aliphatic groups. The $\mathrm{C} / \mathrm{N}$ atomic radius reflects the enrichment of nitrogenous structures in the HA released from the LRC through bacterial activity. The above findings indicate some degree of structural change in the HS associated to its release from coal through bacterial activity.

The strains evaluated in this study were isolated from microhabitats which have been permanently enriched with residues from the extraction, washing and storage of coal (Valero et al., 2012).These strains evidence the biotransforming ability of LRC to produce $\mathrm{SH}$ in vitro. Strains with greater activity are regular soil inhabitants, this fact indicates that, probably under natural conditions, an adaptation of the microbial populations which use and transform coal took place; this fact is reflected in the structural differences found in the HA produced by B. mycoides.

Likewise, it has been observed that, in reconstructed soils from closed coal mines, part of the carbon stabilized on the humified organic matter is derived from coal waste (Dick et al., 2006). Additionally, LRC is humified at a rate of $0.25 \mathrm{~g} . \mathrm{kg}$ of soil $^{-1}$.year ${ }^{-1}$ after the establishment of the microbial community and after an increase of ligninolytic enzymes (Rumpel and Kogel, 2002). In addition, given the content of heavy metals in the LRC, it represents no risk of toxicity, as it does not surpass the maximum permissible limits for contamination with heavy metals if used in natural environments such as soil, in compliance with the Alloway (1995) regulations. On the contrary, LRC can be considered as a source of elements such as $\mathrm{Cu}, \mathrm{Zn}, \mathrm{Mo}, \mathrm{Co}$, and $\mathrm{B}$, which are necessary for plant nutrition. Its elemental composition also provides nutritive elements such as $\mathrm{C}, \mathrm{N}$, $\mathrm{S} \mathrm{Mg}$, and $\mathrm{K}$, which are essential for the development of microorganisms. This composition also provides micronutrients such as $\mathrm{Fe}, \mathrm{Ca}$, and $\mathrm{Mn}$.

In spite of the technical and economic difficulties to carry out the biotransformation of LRC in large scale bioreactors, the findings presented in this paper make it possible to suggest that in situ LRC solubilization using the soil microorganisms involved in complex transformation processes of organic matter can trigger the release of humified organic matter. Thus, this phenomenon may be helpful in soil reclamation processes.

\section{Acknowledgments}

The authors would like to thank the company Carbones del Cerrejón Limited, as well as COLCIENCIAS for sponsoring this research. They also thank the universities Universidad Popular del Cesar, Universidad Nacional de Colombia, and the Research group on Supramolecular Humic Systems in the Environment at Universitat di Napoli Federico II.

\section{References}

Alloway BJ (1995) Heavy Metals in Soils $2^{\text {nd }}$ ed. Blackie Academia Professional, London.

Badis A, Ferradji FZ, Boucherit A, Fodil D, Boutoumi H (2009) Characterization and biodegradation of soil humic acids and preliminary identification of decolorizing actinomycetes at Mitidja plain soil (Algeria). Afr J Microbiol Res 3(13):9971007.

Bandeira M, Mosca G, Vamerali T (2009) Humic acids affect root characteristics of fodder radish (Raphanus sativus L. var. oleiformis Pers.) in metal-polluted wastes. Desalination 246(1-3):78-91.

Barros L, Canellas LP, Lopes F, Oliveira N, Lazaro E, Piccolo A (2010) Bioactivity of chemically transformed humic matter from vermicompost on plant root growth. J Agric Food Chem 58(6):3681-3688.

Canellas LP, Dantas L, Aguiar N, Peres L, Zsogon A, Olivares F, Dobbss L, Facanha A, Nebbioso A, Piccolo A (2011) Probing the hormonal activity of fractionated molecular humic components in tomato auxin mutants. Ann Appl Biol 159(2):202-211.

Dick DP, Knicker H, Avila LG, Inda,AV, Giasson E, Bissani CA (2006) Organic matter in constructed soils from a coal mining area in southern Brazil. Org Geochem 37(11):15371545.

Fakousa, R.; Hofrichter, M. (1999). Biotechnology and microbiology of coal degradation. Appl Microbiol Biotehc 52(1):25-40.

Füchtenbusch B, Steinbüchel A (1999) Biosynthesis of polyhydroxyalkanoates from low-rank coal liquefaction products by Pseudomonas oleovorans and Rhodococcus ruber. Appl Microbiol Biotechnol 52(1):91-95.

Gokcay C, Kolankaya N, Dilek F (2001) Microbial solubilization of lignites. Fuel 80(10):1421-1433.

Hofrichter M (2002) Review: lignin conversion by manganese peroxidase (MnP). Enz Microb Techn 30 (4):454-466. 
Hofrichter M, Fakoussa RM, (2004) Microbial Degradation and modification of coal. In: Steinbüchel, A. (ed). Lignin, Humic Substances and Coal. Wiley-VCH, Weinheim, Germany. pp. 399-425.

Hofrichter M, Fritsche W (1997) Depolymerization of low rank coal by extracellular fungal enzymes systems. III. In vitro depolymerization of coal humic acids by a crude preparations of manganese peroxidase from the white rot fungus Nematoloma frowardii b19. Appl Microbiol Biothecnol 47(5):566-571.

Hofrichter M, Bublitz M, Fritsche M (1997) Fungal attack on coal II. Solubilization of low-rank coal by filamentous fungi. Fuel Proces Techn 52(1-3):55-64.

Hölker U, Höfer M (2002) Solid substrate fermentation of lignite by the coal-solubilizing mould, Trichoderma atroviride, in a new type of bioreactor. Biotech Lett. 24(19):1643-1645.

International Humic Substances Society (IHSS). 2007. Isolation of Soil Fulvic and Humic Acids. Aviable at: http://www.ihss.gatech.edu/soilhafa.html [accesed 20 January 2010].

Laborda F, Fernandez M, Luna N, Monistrol IF (1997) Study of the mechanisms by which microorganisms solubilize and/or liquefy Spanish coals. Fuel Process Techn 52(1-3):95-107.

Lu XQ, Hanna JV, Johnson WD (2000) Source indicators of humic substances: An elemental composition solid state ${ }^{13} \mathrm{C}$ CP/MAS NMR and Py- GC /MS study. Appl Geochem 15(7):1019 - 1023.

Machnikowska H, Pawelec A, Podgorska A (2002) Microbial degradation of low rank coals. Fuel Process Techn 77-78:17-23.

Oboirien BO, Burton SG, Cowan H, Hanison ST (2008) The effect of the partuculate phase on coal biosolubilisation mediated by Trichoderma atroviride in a slurry bioreactor. Fuel Process Techn 89(2):123-130.

Piccolo A (2002) The supramolecular structure of humic substances: a novel understanding of humus chemistry and implications in soil science. Adv Agron 75:57-134.

Piccolo A, Spaccini R, Nieder R (2004) Sequestration of a biologically labile organic carbon in soils by humified organic matter. Climatic Change 67(2-3):329-343.

Pokorny R, Olejníková P, Balog M (2005) Characterization of microorganisms isolated from lignite excavated from the Záhorie coal mine (southwestern Slovakia). Rese Microbiol 156(9):932-943.

Ralph JP, Catcheside DE (1996) Recovery and analysis of solubilised brown coal from cultures of wood-rot fungi. J Microbiol Meth 27(1):1-9.

Ralph JP, Catcheside DE (1997) Transformations of low rank coal by Phanerochaete chrysosporium and other wood-rot fungi. Fuel Process Techn 52(1-3):79-93.

Ralph JP, Catcheside DE (1998) Influence of culture parameters on extracellular peroxidase activity and transformation of low-rank coal by Phanerochaete chrysosporium. Appl Microbiol Biotechnol 49 (4):438-444.

Ralph JP, Catcheside DE (1998b) Involvement of manganese peroxidase in the transformation of macromolecules from low-rank coal by Phanerochaete chrysosporium Appl Microbiol Biotechnol 49 (6):778-784.

Rumpel C, Kogel-Knabner I (2002) The role of lignite in the carbon cycle of lignite-containing mine soils: evidence from carbon mineralisation and humic acid extractions. Organ Geochem 33(3):393-399

Senesi N, Plaza C, Brunetti G, Polo A (2007) A comparative survey of recent results on humic-like fractions in organic amendments and effects on native soil humic substances. Soil Biol Biochem 39 (6):1244-1262.

Sharif M, Khattak RA., Sarir MS (2002) Effect of different levels of lignitic coal derived humic acid on growth of maize plants. Commun Soil Sci Plant Anal 33(19):3567-3580.

Steinbüchel A (2001) Biopolymers, Lignin, Humic Substances and Coal. Wiley, Weinheim, Germany.

Stevenson FJ (2004) Humus chemistry: Genesis, composition and reactions. Jhon Wiley \& Sons Inc, New York.

Strandberg G, Lewis S (1987) Solubilization of coal by an extracellular product from Streptomyces setonii $75 \mathrm{Vi2}$. J Ind Microb 1(6):371-375.

Trevisan S, Francioso O, Quaggiottil S, Nardi S (2010) Humic substances biological activity at the plant-soil interface From environmental aspects to molecular factors. Plant Sig Beh 5(6):635-643.

Valero N, Beleño J, Mancilla S (2011) Biotransformación de carbón de bajo rango por bacterias aisladas de microhábitats influenciados por residuos de carbón. Rev Col Biotec 13(1):58-65.

Valero N, Rodríguez LN, Mancilla S, Contreras L (2012) Obtención de bacterias biotransformadoras de carbón de bajo rango a partir de microhábitats con presencia de residuos carbonosos. Acta Biol Colom 17(2):335-348.

Willmann G, Fakoussa R (1997) Extracellular oxidative enzymes of coal-attacking fungi. Fuel Proces Tech 52(1-3):27-41.

Yin SD, Tao X, Shi KY (2009) Bio-solubilization of Chinese lignite II: protein adsorption onto the lignite surface. Min Sc Tech 19(3):363-368.

Yuan H, Yang J, Chen W (2006) Production of alkaline materials, surfactants and enzymes by Penicillium decumbens strain P6 in association with lignite degradation/solubilization. Fuel 85(10-11):1378-1382.

Zaavarzinda AG, Leontievskyb AA, Golovlevab LA, Trofimova SY (2004) Biotransformation of soil humic acids by blue laccase of Panus tigrinus 8/18: an in vitro study. Soil Biol Bioch 36(2):359-369.

All the content of the journal, except where otherwise noted, is licensed under a Creative Commons License CC BY-NC. 